\title{
Nucleotide Sequencing, Whitefly Transmission, and Screening Tomato for Resistance Against Two Newly Described Begomoviruses in Bangladesh
}

\author{
M. N. Maruthi, S. N. Alam, K. A. Kader, A. R. Rekha, A. Cork, and J. Colvin
}

First, fourth, fifth, and sixth authors: Natural Resources Institute, University of Greenwich, Central Avenue, Chatham Maritime, Kent ME4 4TB, UK; and second and third authors: Bangladesh Agricultural Research Institute, Joydebpur, Gazipur, Bangladesh. Accepted for publication 18 August 2005.

\begin{abstract}
Maruthi, M. N., Alam, S. N., Kader, K. A., Rekha, A. R., Cork, A., and Colvin, J. 2005. Nucleotide sequencing, whitefly transmission, and screening tomato for resistance against two newly described begomoviruses in Bangladesh. Phytopathology 95:1472-1481.

The molecular diversity of Tomato leaf curl viruses (ToLCVs), from the two main tomato growing areas of Jessore and Joydebpur, Bangladesh, was investigated. The viral DNA was amplified from tomato plants exhibiting mild and severe symptoms by polymerase chain reaction, and the complete genomes of the ToLCVs were sequenced. An isolate of the bipartite Tomato leaf curl New Delhi virus-Severe (ToLCNDV-Svr) was associated with the severe symptom phenotype from Jessore (ToLCNDVSvr[Jes]). A previously undescribed monopartite virus, designated Tomato leaf curl Joydebpur virus-Mild (ToLCJV-Mld), was sequenced from

DNA-A and -B component sequences. ToLCJV-Mld was similar to Pepper leaf curl Bangladesh virus at $87.1 \%$ DNA-A nt identity. Identification of ToLCNDV-Svr[Jes] and ToLCJV-Mld was in addition to the previously described Tomato leaf curl Bangladesh virus, with which they shared 73.2 and $86.0 \%$ DNA-A nt identities, thus demonstrating the existence of at least three distinct viruses infecting tomato in Bangladesh. Nucleotide identities and placement in phylogenetic trees suggested that the three ToLCVs may have had different evolutionary pathways. The whitefly, Bemisia tabaci, transmitted the viruses of this study equally efficiently. Four tomato cultivars (TLB111, TLB130, TLB133, and TLB182) resistant/tolerant to South Indian ToLCV were screened against the Bangladesh ToLCVs in 2003-04. Although challenged by diverse viruses and potentially mixed infections, disease incidence remained low (6 to 45\%) in the resistant cultivars compared with local cultivars (68 to 100\%).
\end{abstract} plants showing mild symptoms. ToLCNDV-Svr[Jes] was most closely related to ToLCNDV-[Lucknow] at $95.7 \%$ nucleotide (nt) identity and Tomato leaf curl Gujarat virus-[Varanasi] at $90.6 \%$ nt identity, based on
Additional keywords: Geminiviridae, phylogeny, whitefly vector.
Tomato (Lycopersicon esculentum Mill.) is an economically important cash crop for resource-poor farmers in Bangladesh. It is grown mainly during the winter season (November to February), because the lack of heat-tolerant cultivars limits tomato cultivation during the hot summer months (March to August). In both seasons, however, production is severely constrained by tomato leaf curl virus disease (ToLCVD).

ToLCVD was first documented in Bangladesh only recently $(11,21)$, although it is likely to have occurred earlier since the disease had been recorded in the neighboring areas of northern and central India since the 1950s $(43,44)$. In susceptible cultivars, ToLCVD symptoms include yellowing, vein clearing, severe leaf curling, and stunting of the plant. If infection occurs at the seedling stage, plants become sterile causing up to $100 \%$ yield loss (38).

ToLCVD is caused by a range of Tomato leaf curl viruses (ToLCVs) of the genus Begomovirus, family Geminiviridae $(9,10)$. ToLCVs may be monopartite or bipartite, depending on whether they have one or two DNA components. Bipartite species have two circular single-stranded DNA components called DNA$A$ and DNA-B. DNA-A encodes two genes on the virus strand, the coat protein (AV1 or $\mathrm{CP}$ ) and AV2, and four genes on the complementary strand, the replication-associated protein (AC1 or Rep), transcriptional activator protein (AC2 or TrAP), replication en-

Corresponding author: M. N. Maruthi

E-mail address: M.N.Maruthi@greenwich.ac.uk

DOI: 10.1094/PHYTO-95-1472

(C) 2005 The American Phytopathological Society hancer protein (AC3 or REn), and AC4. The virus and complementary strands of DNA-B each contain one gene, the nuclear shuttle protein (BV1 or NSP) and movement protein (BC1 or MP), respectively. A common region $(\mathrm{CR})$ sequence of near identity shared between DNA-A and -B contains promoters and iteron sequences involved in virus replication $(12,13)$.

Monopartite begomovirus species lack the DNA-B component and have been mostly isolated from tomato and cotton $(5,8$, 18,34). More recently, additional satellite DNA molecules, called DNA- $\beta$, DNA1, and their mutants were found to be associated with monopartite viruses $(2,3,5,39,40)$. Most of the DNA- $\beta$ molecules are approximately half the size $(\approx 1,350$ bases $)$ of DNA-A, except for some deletion mutants that are a quarter the size ( $\approx 680$ bases) $(3,45)$. A DNA- $\beta$ is essential for disease expression in some begomovirus complexes $(2,5)$, whereas DNA1 and its mutants modulate symptom phenotype in others $(3,41)$.

A monopartite begomovirus species, Tomato leaf curl Bangladesh virus (ToLCBDV), was shown previously to be associated with ToLCVD in Bangladesh (11). In the research presented here, two other viruses were detected and characterized: Tomato leaf curl New Delhi virus-Severe from Jessore (ToLCNDV-Svr[Jes]) (28) and a previously undescribed species, Tomato leaf curl Joydebpur virus-Mild (ToLCJV-Mld) from Joydebpur (27). These viruses were associated with severe and mild ToLCVD symptoms, respectively.

The usual control method employed against ToLCVD has been the use of insecticides targeted at infective immigrant adult whitefly, Bemisia tabaci (Gennadius) (Hemiptera; Aleyrodidae), that transmit ToLCVs into and within tomato crops. In the recent past, however, three high-yielding tomato cultivars resistant/tolerant to 
South Indian ToLCVs were developed that can be grown successfully with minimal insecticide use (31). These cultivars were screened for resistance to ToLCVs in Bangladesh to test their suitability to this new area. The virus variability molecular studies were carried out to improve the efficacy with which further ToLCV-resistant material is screened, and to investigate resistant tomato genotype-virus interactions.

\section{MATERIALS AND METHODS}

ToLCV isolates and B. tabaci colony. Tomato shoots with young leaves showing mild (cv. TLB 182) or severe (cv. BARI Tomato $5=$ BT5) ToLCVD symptoms were collected in September 2003 from experimental fields at the Bangladesh Agricultural Research Institute (BARI), Jessore, and from Joydebpur in Bangladesh. The virus isolates were transported to the Natural Resources Institute (NRI), UK, in plastic bags kept in cool conditions. The viruses were transmitted to healthy tomato seedlings (cv. Moneymaker) in the quarantine insectary of NRI using adult B. tabaci. The whitefly colony was established with $B$. tabaci collected on brinjal (eggplant) in the BARI glasshouse and maintained on brinjal at NRI in cages $(20 \mathrm{~cm} \times 20 \mathrm{~cm} \times 40 \mathrm{~cm})$ covered with 40-mesh size nylon net, as described previously (23). Cytochrome oxidase I gene sequence data obtained from this colony classified it as andigenous $B$. tabaci population (M. N. Maruthi, A. R. Rekha, J. Colvin, and V. Muniyappa, unpublished data).

Virus-vector transmission relationships. The experimental protocol described by Pico et al. (36) was followed for the transmission of a field-collected ToLCV isolate in the BARI glasshouse. Adult B. tabaci were collected using an aspirator from a colony established on brinjal plants in cages $(30 \mathrm{~cm} \times 30 \times 30 \mathrm{~cm})$. For virus acquisition, insects were placed in a plastic tube containing a tomato plant shoot expressing severe ToLCVD symptoms. About 10-day-old healthy tomato plants, cv. BT5, were inoculated either individually, enclosed in plastic cylindrical cages $(3 \times 8 \mathrm{~cm})$, or en masse under a nylon net by releasing viruliferous whiteflies. After virus inoculation, whiteflies were killed by spraying $0.1 \%$ imidacloprid (Admire, Bangladesh). ToLCVD symptoms were recorded weekly for 2 months. Each of the following virus-vector relationship experiments was repeated three times and each replicate had at least six BT5 target plants.

The minimum number of $B$. tabaci adults required to transmit ToLCV was determined. Whiteflies were allowed to feed on infected plants for a 24-h acquisition access period (AAP) and were then released in groups of 1,2, 5, 10, and 15 on BT5 test plants for a 24-h inoculation access period (IAP).
The optimum AAP required for the transmission of ToLCV was determined by feeding $B$. tabaci adults on infected plants for periods of 5, 10, 15, and $30 \mathrm{~min}$, and 1, 6, 12, and $24 \mathrm{~h}$. Groups of 10 viruliferous whiteflies were then provided with the opportunity to inoculate each test plant (28 to 33 plants per treatment) for a 24-h IAP.

The optimum IAP required for transmission of ToLCV was determined by feeding $B$. tabaci adults on infected plants for a 24-h AAP. Groups of 10 viruliferous $B$. tabaci then inoculated each of the 28 to 33 BT5 test plants for 5, 10, 15, and $30 \mathrm{~min}$, and 1, 3, 6, 12, and 24-h IAP.

Tomato plants aged $1,2,3,4,5$, and 6 weeks after germination were inoculated with ToLCV using 10 viruliferous $B$. tabaci per plant. These insects were given a 24-h AAP and IAP each and 23 to 32 plants were tested in each age group.

Detection of ToLCV isolates by polymerase chain reaction. Total DNA was extracted from tomato leaves showing mild or severe ToLCVD symptoms using the modified CTAB (cetyl trimethyl ammonium bromide) method (24). Polymerase chain reactions (PCRs) were carried out $(24,30)$ using the Deng A and B primers (7) that amplify $\approx 530$-bp PCR product of DNA-A. Primers ToLCV-B1500F and ToLCV-B1100R (Table 1) were used to amplify $\approx 2.3-\mathrm{kb}$ PCR product of DNA-B. PCR products of partial DNA-A and -B were cloned and sequenced, and the information was used to design virus-specific primers to amplify the full-length DNA-A and -B components (Table 1). Universal primers were used to amplify the satellite DNA- $\beta$ molecule (4).

Sequencing the complete genome of ToLCV isolates. The complete genome of ToLCV isolates were PCR-amplified using primers listed in Table 1, cloned into pGEM-T Easy vector (Promega UK Ltd., Southampton), and sequenced at the MRC Geneservice, Cambridge, UK. Three independent clones of each virus were sequenced to ensure sequence identity and reliability. Minor discrepancies in sequences were corrected manually using the software package DNAStar (DNAStar Inc., Madison, WI). Phylogenetic analyses were carried out to generate parsimonious trees using phylogenetic analysis using parsimony (PAUP) 4.0 version 10 beta for Mac (Sinauer Associates, Sunderland, MA; 42) with bootstrapping for 100 replicates. Sequences of ToLCVs were compared with sequences of selected begomoviruses obtained from the database (Table 2), as described previously (22).

Screening for resistance to ToLCV in the field in Bangladesh. One-month-old tomato plants of four cultivars (TLB111, TLB130, TLB133, and TLB182) that were resistant/tolerant to South Indian ToLCVs (31) and four local cultivars (BARI Tomato 2 [BT2], BARI Tomato 3 [BT3], BT5, and BARI Tomato 10 [BT10]) were planted in June 2003 in the fields of Jessore and

TABLE 1. Primers used for the polymerase chain reaction-amplification of Tomato leaf curl Joydebpur virus-Mild (ToLCJV-Mld) and Tomato leaf curl New Delhi virus-Severe from Jessore (ToLCNDV-Svr[Jes]) genome

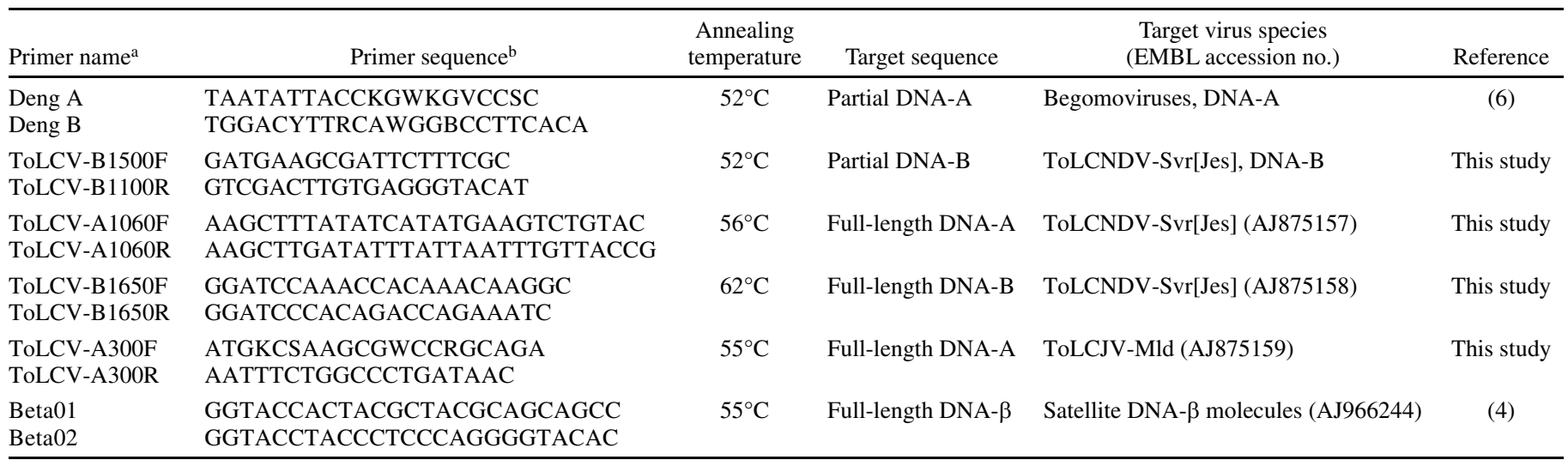

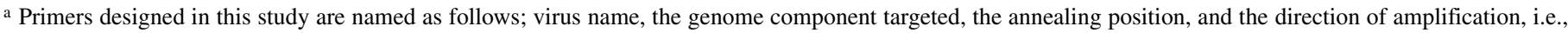
$\mathrm{F}$ for forward primer amplifying on the +ve strand and the $\mathrm{R}$ for reverse primer amplifying the -ve strand.

${ }^{\mathrm{b}}$ Coding for nucleotides follows the international standard where, $\mathrm{K}=\mathrm{G}+\mathrm{T}, \mathrm{W}=\mathrm{A}+\mathrm{T}, \mathrm{V}=\mathrm{G}+\mathrm{A}+\mathrm{C}, \mathrm{S}=\mathrm{G}+\mathrm{C}, \mathrm{Y}=\mathrm{C}+\mathrm{T}, \mathrm{R}=\mathrm{A}+\mathrm{G}, \mathrm{and} \mathrm{B}=\mathrm{G}+\mathrm{T}+\mathrm{C}$. 
Joydebpur. Transplanting was conducted in four rows of six plants, each at a spacing of $1.0 \times 0.6 \mathrm{~m}$. A randomized complete block design was used with three replications containing 20 to 24 plants per cultivar. ToLCVD incidence (percent infected plants) and disease severity index were recorded fortnightly for 2 months. The disease index was assessed on a four-point scale of 0 to 3 , where $0=$ no infection (no visible symptoms), $1=$ mild infection (slight yellowing of leaves), 2 = moderate infection (interveinal yellowing, leaf curling, and stunting of the plant), and $3=$ severe infection (severe leaf curling and yellowing, reduction in leaf size, severe stunting, and no fruit setting). The mean disease index was calculated by dividing the total index score by the total number of diseased plants. The experiments were repeated at both locations in the 2003-04 winter season (November to February).

Screening by graft transmission in the glasshouse. Ten plants each of the three resistant/tolerant tomato cultivars, TLB111, TLB130, TLB182, and the susceptible cv. Moneymaker, were graftinoculated with severe ToLCNDV-Svr[Jes] and mild ToLCJV-Mld in the NRI quarantine glasshouse. A diseased scion was placed in an incision made on each 1-month-old healthy plant and secured tightly using a strip of Parafilm. Scions were enclosed in selfsealable plastic bags for 1 month to avoid desiccation. Development of ToLCVD symptoms was recorded for 3 months.

\section{RESULTS}

Symptom phenotype of mild and severe ToLCVs. ToLCJVMld produced mild symptoms of faint yellowing and slight curling on the young leaves of cv. Moneymaker tomato plants (Fig. 1A). As the disease progressed, yellowing became prominent on some older leaves producing mosaic-like symptoms (Fig. 1B), which is not common to ToLCVs. ToLCJV-Mld also produced typical disease symptoms of leaf yellowing and curling, and plant growth was only slightly affected (Fig. 1D).

The severe ToLCNDV-Svr[Jes] caused yellowing, severe curling, deformation of leaves, twisting of stems, and drastically reduced leaf size (Fig. 1C). Plants became sterile, severely stunted with shortened internodes, and appeared bushy (Fig. 1E). Unlike symptoms caused by ToLCJV-Mld, the yellowing did not develop into mosaic-like symptoms.

Virus transmission studies. Single $B$. tabaci adults transmitted a field isolate of ToLCV with $10 \%$ efficiency. Groups of two and five adults achieved 20 and $50 \%$ transmission rates, respectively, and 10 and $15 \mathrm{~B}$. tabaci per test plant each achieved $90 \%$ transmission at BARI. The latter result was comparable to the $100 \%$ transmission rates achieved with both ToLCNDV-Svr[Jes] and ToLCJV-Mld in the NRI insectary using $10 \mathrm{~B}$. tabaci per test plant. The symptom expression at NRI was typical of that observed under field conditions for the respective isolates.

At BARI, B. tabaci adults acquired ToLCV in $30 \mathrm{~min}$ (minimum AAP) to give $4 \%$ transmission efficiency, which increased to $85 \%$ with 24 -h AAP (Table 3). Viruliferous adults required a minimum IAP of 15 min to transmit the virus with $3 \%$ efficiency, which increased to $84 \%$ following a 24 -h IAP.

The susceptibility of cv. BT5 plants to ToLCV was inversely related to their age. About $80 \%$ of the 1-week-old seedlings were infected and expressed symptoms as early as 2 weeks after inoculation. Subsequent age groups were found to be less susceptible to ToLCVD with infection rates of $75,50,33,18,18$, and $13 \%$, respectively, for the 2, 3, 4, 5, 6, and 7-week-old seedlings.

PCR-mediated detection and genome organization of viruses. The Deng A and B primers amplified the expected PCR products of size $\approx 530 \mathrm{bp}$ from the genome of ToLCJV-Mld and ToLCNDVSvr[Jes]. The ToLCV-B1500F and ToLCV-B1100R primers amplified the expected PCR products of size $\approx 2.3 \mathrm{~kb}$ from the samples of ToLCNDV-Svr[Jes] only. DNA- $\beta$-specific primers also amplified the expected $\approx 1,300 \mathrm{bp}$ from ToLCJV-Mld samples.

The full-length DNA-A and -B component sequences of ToLCNDV-Svr[Jes] were 2,740 and 2,688 nucleotides (nts), respectively. DNA-A and $-\beta$ sequences of ToLCJV-Mld were 2,761 and 1,366 nts, respectively. These sequences are available in the EMBL, GenBank, and DDBJ databases under accession

TABLE 2. The begomovirus species/strains used in comparative phylogenetic analyses, together with their abbreviations and accession numbers

\begin{tabular}{|c|c|c|}
\hline Virus species/ strains & Abbreviation & EMBL accession no. \\
\hline Bean golden yellow mosaic virus-[Mexico] & BGYMV-[MX] & AF173555, AF173556 \\
\hline Bhendi yellow vein mosaic virus-[Madurai] & BYVMV-[Mad] & AF241479 \\
\hline Cotton leaf curl Rajasthan virus & CLCuRV & AF363011 \\
\hline East African cassava mosaic Zanzibar virus & EACMZV & AF422174, AF422175 \\
\hline Indian cassava mosaic virus-[Maharastra] & ICMV-[Mah] & AF314740, AF314739 \\
\hline Papaya leaf curl virus-[Cotton] & $\mathrm{PaLCuV}-[\mathrm{Cot}]$ & AJ436992 \\
\hline Pepper leaf curl Bangladesh virus & PepLCBV & AF314531 \\
\hline Squash leaf curl China virus-[Pumpkin:Coimbatore] & SLCCNV-[Pum:Coi] & AY184487, AY184488 \\
\hline Squash leaf curl virus & SLCV & M38182, M38183 \\
\hline Sri Lankan cassava mosaic virus-[Colombo] & SLCMV-[Col] & AJ314738, AJ314737 \\
\hline Squash leaf curl Yunnan virus & SLCYV & AJ420319 \\
\hline Tobacco leaf curl Kochi virus-[KK] & TbLCKoV-[KK] & AB055009 \\
\hline Tomato leaf curl Bangalore virus & ToLCBV & Z48182 \\
\hline Tomato leaf curl Bangalore virus-[Banglore 4] & ToLCBV-[Ban4] & AF165098 \\
\hline Tomato leaf curl Bangalore virus-[Bangalore 5] & ToLCBV-[Ban5] & AF295401 \\
\hline Tomato leaf curl Bangalore virus-[Kolar] & ToLCBV-[Kol] & AF428255 \\
\hline Tomato leaf curl Bangladesh virus & ToLCBDV & AF188481 \\
\hline Tomato leaf curl Gujarat virus-[Varanasi] & ToLCGV-[Var] & AY190290, AY190291 \\
\hline Tomato leaf curl Karnataka virus & ToLCKV & U38239 \\
\hline Tomato leaf curl Malaysia virus & ToLCMV & AF327436 \\
\hline Tomato leaf curl New Delhi virus-[Lucknow] & ToLCNDV-[Luc] & Y16421, X89653 \\
\hline Tomato leaf curl New Delhi virus-[Luffa] & ToLCNDV-[Luf] & AF102276 \\
\hline Tomato leaf curl New Delhi virus-Mild & ToLCNDV-Mld & U15016 \\
\hline Tomato leaf curl New Delhi virus-[Potato] & ToLCNDV-[Pot] & AY286316, AY158080 \\
\hline Tomato leaf curl New Delhi virus-Severe & ToLCNDV-Svr & $\mathrm{U} 15015, \mathrm{U} 15017$ \\
\hline Tomato leaf curl Philippines virus & ToLCPV & $\mathrm{AB} 050597$ \\
\hline Tomato leaf curl Sri Lanka virus & ToLCSLV & AF274349 \\
\hline Tomato leaf curl Taiwan virus & ToLCTWV & U88692 \\
\hline Tomato leaf curl virus-[AU] & ToLCV & S53251 \\
\hline Tomato yellow leaf curl China virus & TYLCCNV & AF311734 \\
\hline Tomato yellow leaf curl Thailand virus-[1] & TYLCTHV-[1] & X63015, X63016 \\
\hline Tomato yellow leaf curl virus & TYLCV & $\mathrm{X} 15656$ \\
\hline
\end{tabular}


nos. AJ875157 to AJ875159 and AJ966244. A CR of 164 nts was identified in DNA-A and -B sequences of ToLCNDV-Svr[Jes], which shared $91.4 \%$ nt identity for the cognate viral components. Comparison of an equivalent region of ToLCJV-Mld with the CR of A and B components of ToLCNDV-Svr[Jes] showed 69.1 and $63.6 \%$ nt identities, respectively, indicating that DNA-A of ToLCJV-Mld and DNA-B of ToLCNDV-Svr[Jes] are not cognate. In addition, detection of DNA- $\beta$ suggests that ToLCJVMld is a monopartite virus. The CR of all four components contained the nonanucleotide sequence TAATATTAC that is conserved in the stem loop of all begomoviruses, which has the DNA nicking site for the initiation of viral replication. A TATAbox and the predicted repeated iteron sequences (GGTGT) involved in binding of Rep during viral replication were present in the CR of both viruses (Fig. 1, bottom panel). ToLCJV-Mld was atypical in that it had three iteron sequences within the CR.
ToLCNDV-Svr[Jes] also had three iterons but with a base substitution (GGAGT).

The total number of open reading frames (ORFs) predicted differed for each virus component. However, DNA-A of both viruses was predicted to encode six genes each (CP, AV2, Rep, TrAP, REn, and AC4), DNA-B of ToLCNDV-Svr[Jes] to encode two genes (NS and MP), and DNA- $\beta$ to encode one gene $(\beta C 1)$ (Fig. 2) that are commonly found in Old World begomoviruses. The genome maps of virus components showing the relative positions of each conserved gene are presented in Figure 2. The genes were encoded on both the virion and complementarysense strands and their size and arrangement were typical of begomoviruses of the genus Begomovirus, family Geminiviridae (Table 4). In addition, an unknown ORF of 849 nts (282 amino acids) was predicted to occur on the complimentary strand between nucleotide positions $1139 \rightarrow 291$, beginning from the $5^{\prime}$
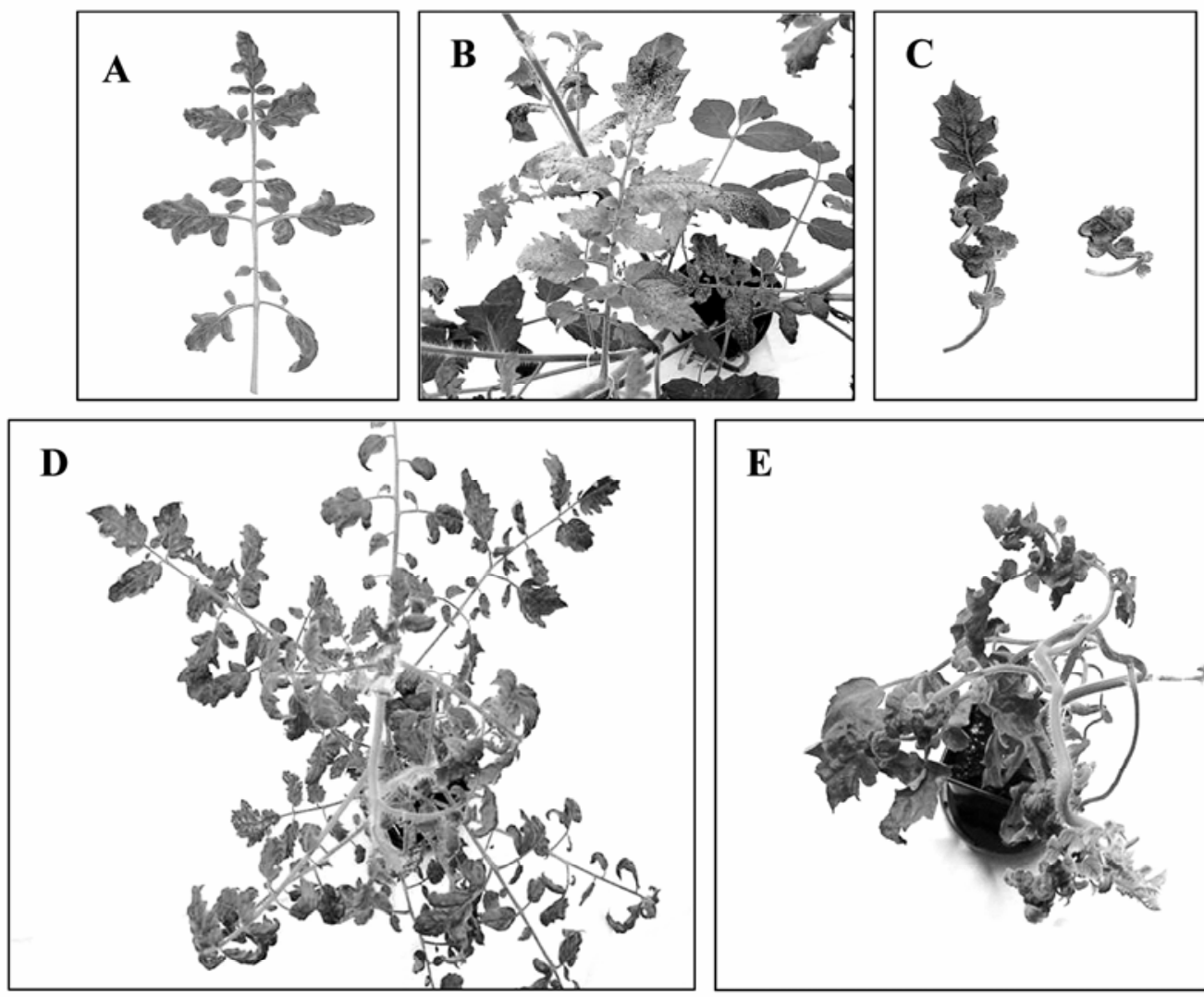

$\mathbf{E}$

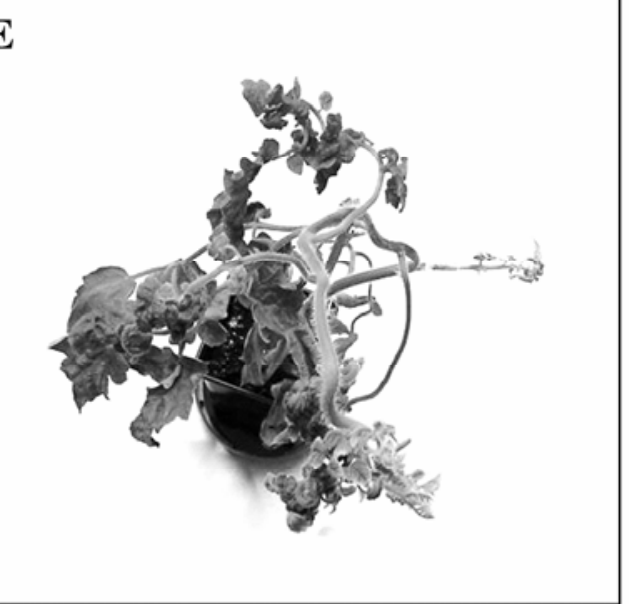

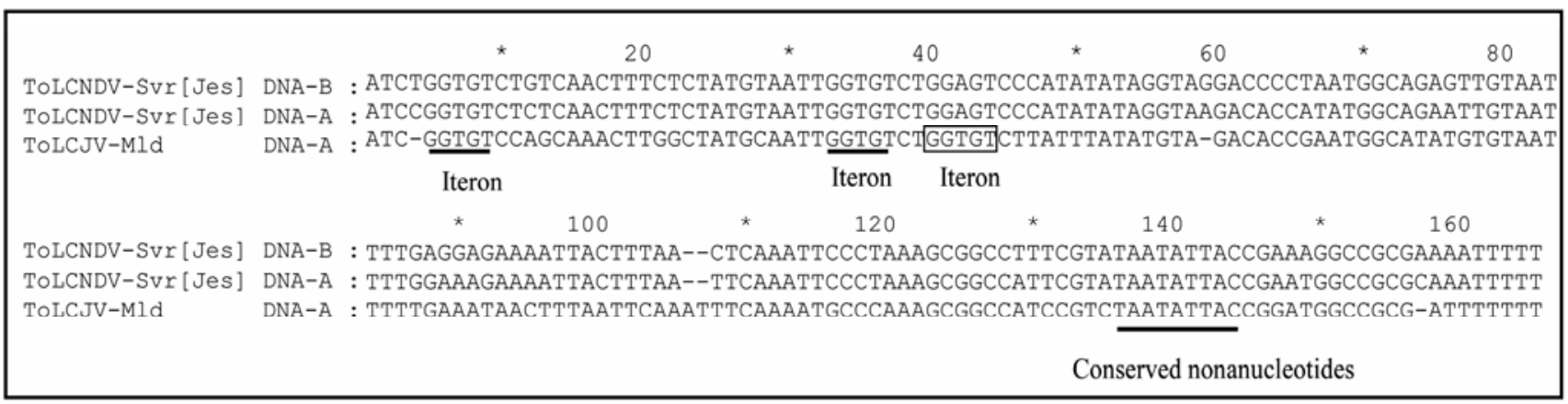

Fig. 1. Top, Characteristic symptoms produced by Tomato leaf curl virus (ToLCV) isolates. A, Faint yellowing, B, mosaic-like symptoms on leaves, and $\mathbf{D}$, yellowing and curling developed on tomato plants (cv. Moneymaker) infected by Tomato leaf curl Joydebpur virus-Mild (ToLCJV-Mld); and C, severely deformed leaves and E, stunted plant infected by Tomato leaf curl New Delhi virus-Severe from Jessore (ToLCNDV-Svr[Jes]). Bottom, The common region sequences of ToLCNDV-Svr[Jes] and ToLCJV-Mld genome components. The conserved nonanucleotide sequences, TATA-box and predicted replication-associated protein (Rep)-binding sites (iterons) are underlined. Presence of an additional iteron sequence unique to ToLCJV-Mld is boxed. 
end of REn and ending on the 5' end of AV2, encompassing the entire length of the CP gene (Fig. 2), in what is the most conserved region of begomoviruses (15). The function of the new ORF is unknown and requires further investigation, as an ORF with similar features also was found to occur in Pepper leaf curl Bangladesh virus (PepLCBV).

Sequence analyses. Comparison of genome sequences and the construction of phylogenies based on DNA-A and CP sequences with other begomoviruses clustered ToLCJV-Mld and ToLCNDV$\mathrm{Svr}$ [Jes] into the mono- and bipartite groups, respectively, and are shown in Figure 3A and B. Based on DNA-A sequences, ToLCNDV-Svr[Jes] was most closely related to Tomato leaf curl

TABLE 3. Determination of acquisition access periods (AAP) and inoculation access periods (IAP) required by adult Bemisia tabaci for the transmission of a field isolate of Tomato leaf curl virus from Joydebpur, Bangladesh

\begin{tabular}{llc}
\hline & \multicolumn{2}{c}{ No. of plants infected/inoculated $(\%)^{\mathrm{a}}$} \\
\cline { 2 - 3 } Time period & $\mathrm{AAP}^{\mathrm{b}}$ & $\mathrm{IAP}^{\mathrm{c}}$ \\
\hline $5 \mathrm{~min}$ & $0 / 22$ & $0 / 27$ \\
$10 \mathrm{~min}$ & $0 / 33$ & $0 / 21$ \\
$15 \mathrm{~min}$ & $0 / 24$ & $1 / 26(3.8)$ \\
$30 \mathrm{~min}$ & $1 / 22(4.5)$ & $2 / 21(9.5)$ \\
$1 \mathrm{~h}$ & $5 / 30(16.6)$ & $4 / 18(22.2)$ \\
$3 \mathrm{~h}$ & $7 / 21(33.3)$ & $7 / 26(26.9)$ \\
$6 \mathrm{~h}$ & $15 / 29(51.7)$ & $10 / 24(41.6)$ \\
$12 \mathrm{~h}$ & $24 / 32(75.0)$ & $20 / 28(71.4)$ \\
$24 \mathrm{~h}$ & $22 / 26(84.6)$ & $21 / 25(84.0)$ \\
\hline
\end{tabular}

a Values are the total number of plants used in experiments with three replicates, and in each replicate at least six plants were inoculated.

${ }^{\mathrm{b}}$ One-week-old tomato cv. BT5 plants were each inoculated with 10 viruliferous B. tabaci, which were given a 24-h IAP.

${ }^{c}$ One-week-old tomato cv. BT5 plants were each inoculated with 10 viruliferous B. tabaci, which were given a 24-h AAP.
Gujarat virus-[Varanasi] (ToLCGV-[Var]) at 97.5\% nt identity (Table 5) and grouped with other strains of ToLCNDV and Squash leaf curl China virus-Pumpkin[Coi] (SLCCNVPum[Coi]) (Fig. 3A). Thus, ToLCNDV-Svr[Jes] was considered a strain of ToLCNDV. The monopartite group was subdivided into two clades; one contained strains of Tomato leaf curl Bangalore virus (ToLCBV) and Tomato leaf curl Sri Lanka virus (ToLCSLV), and the other a group of viruses infecting diverse crops. ToLCJV-Mld clustered closely with PepLCBV and Papaya leaf curl virus $(\mathrm{PaLCuV})$ in the diverse group with $84 \%$ bootstrap support, being most closely related to PepLCBV at 87.1\% DNA-A nt identity (Fig. 3A, Table 5).

Comparison of complete satellite DNA- $\beta$ sequences by DNA Star software program showed that the ToLCJV-Mld DNA- $\beta$ sequences were most similar at $59.0 \%$ nt identity with DNA- $\beta$ molecules isolated from ToLCVD in India (AY438558).

Phylogenetic comparison of complete $\mathrm{CP}$ gene sequences placed ToLCNDV-Svr[Jes] into the bipartite group with other strains of ToLCNDV and SLCCNV-Pum[Coi] with $100 \%$ bootstrap support (Fig. 3B). All four genes of DNA-A of ToLCNDVSvr[Jes] were well conserved with $\geq 95 \%$ nt identities to strains of ToLCNDV and the two genes of DNA-B with $\geq 91 \% \mathrm{nt}$ identities (Table 5). The division of the monopartite group into two independent clades was less obvious using the CP gene sequences than with those of DNA-A (Fig. 3B). However, ToLCJVMld clustered closely with PepLCBV with $100 \%$ bootstrap support and shared the highest nucleotide identity (97.5\%). All the genes of ToLCJV-Mld were well conserved at 92 to $98 \%$ nt identities to PepLCBV, suggesting that these two viruses have common ancestors. However, ToLCJV-Mld Rep was most similar to ToLCBDV at $88.3 \%$ (Table 5), indicating the possible emergence of ToLCJV-Mld by recombination between PepLCBV and ToLCBDV.
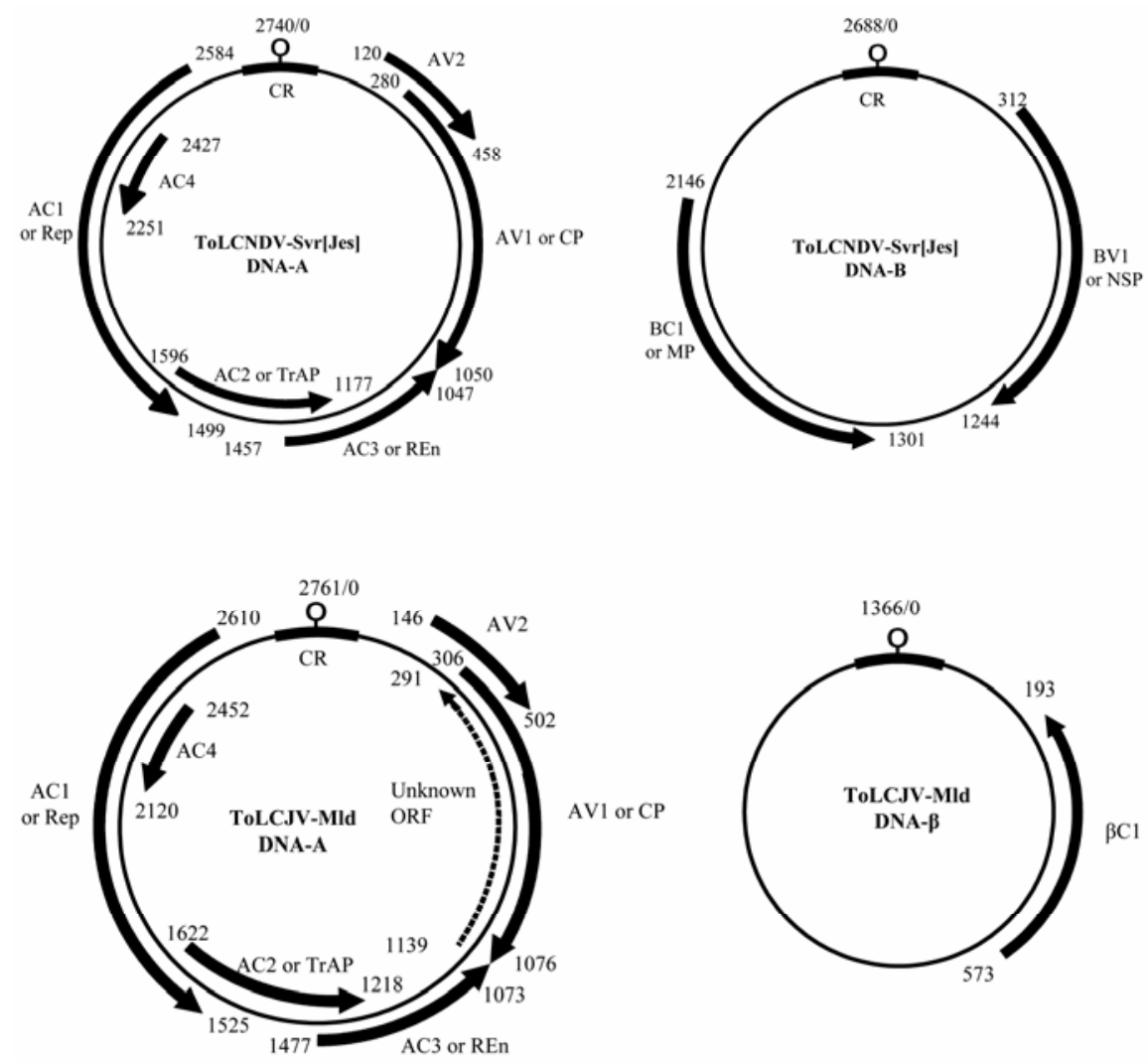

Fig. 2. Genome maps of Tomato leaf curl New Delhi virus-Severe from Jessore (ToLCNDV-Svr[Jes]) and Tomato leaf curl Joydebpur virus-Mild (ToLCJV-Mld). The numbering of nucleotides on the maps follows the geminivirus convention. The numbers (nucleotide positions) referred to the start and stop coordinates and the orientation of open reading frames (ORFs) are shown as an arrow. The position and orientation of an unknown ORF on the DNA of ToLCJV-Mld is shown as an arrow with dotted lines. 
ToLCBDV (11), ToLCJV-Mld, and ToLCNDV-Svr[Jes] were distinct from each other, based on DNA-A sequences. ToLCBDV was most similar to ToLCJV-Mld at $86.0 \%$ nt identity, and clustered in the same clade, but with lower bootstrap support at $67 \%$ (Fig. 3A). ToLCNDV-Svr[Jes] formed a separate clade and shared only $73.2 \%$ nt identity with ToLCBDV (Table 5). Mild and severe strains of ToLCNDV have been reported before $(10,35)$ and they shared 93.7 and $93.8 \%$ DNA-A nt identities, respectively, with ToLCNDV-Svr[Jes].

Resistance of tomato cultivars. The results of the summer and winter screening trials in Jessore and Joydebpur during 2003-04 were concordant. ToLCVD incidence and severity in the resistant/tolerant cultivars varied slightly between locations and seasons, but remained consistently low (Table 6). The maximum $(15 \%)$ of cv. TLB130 plants became infected in the summer trial at Joydebpur compared with $79 \%$ of the local check, cv. BT10. Disease spread was slow in resistant cultivars compared with that of the local susceptible checks, in which disease incidence increased rapidly 1 month after transplanting (Fig. 4A). ToLCVD incidences at Jessore were comparatively higher than at Joydebpur in the resistant/tolerant cultivars with a maximum of $31 \%$ of cv. TLB133 plants infected. Incidence remained high in local checks and was greatest $(75 \%)$ in BT10.

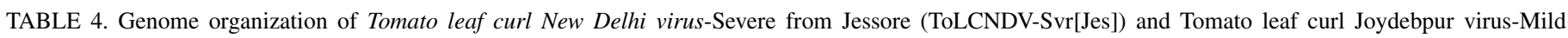
(ToLCJV-Mld)

\begin{tabular}{|c|c|c|c|c|c|c|c|c|}
\hline \multirow{2}{*}{$\begin{array}{l}\text { Open reading } \\
\text { frame }(\mathrm{ORF}) \\
(\text { gene })^{\mathrm{a}}\end{array}$} & \multicolumn{4}{|c|}{ ToLCNDV-Svr[Jes] } & \multicolumn{4}{|c|}{ ToLCJV-Mld } \\
\hline & $\begin{array}{l}\text { Nucleotide } \\
\text { positions }^{b}\end{array}$ & $\begin{array}{c}\text { No. of } \\
\text { nucleotides }\end{array}$ & $\begin{array}{c}\text { No. of } \\
\text { amino acids }\end{array}$ & $\begin{array}{l}\text { Molecular } \\
\text { mass }(\mathrm{kDa})^{\mathrm{c}}\end{array}$ & $\begin{array}{c}\text { Nucleotide } \\
\text { positions }^{b}\end{array}$ & $\begin{array}{c}\text { No. of } \\
\text { nucleotides }\end{array}$ & $\begin{array}{c}\text { No. of } \\
\text { amino acids }\end{array}$ & $\begin{array}{c}\text { Molecular } \\
\text { mass }(\mathrm{kDa})^{\mathrm{c}}\end{array}$ \\
\hline $\mathrm{CP}$ or AV1 & $280-1,050$ & 771 & 256 & 29.56 & $306-1076$ & 771 & 256 & 29.61 \\
\hline AV2 & $120-458$ & 339 & 112 & 13.00 & $146-502$ & 357 & 118 & 13.63 \\
\hline Rep or AC1 & $1,499-2,584$ & 1,086 & 361 & 41.02 & $1,525-2,610$ & 1,086 & 361 & 40.57 \\
\hline TrAP or AC2 & $1,177-1,596$ & 420 & 139 & 15.7 & $1,218-1,622$ & 405 & 134 & 15.22 \\
\hline REn or AC3 & $1,047-1,457$ & 411 & 136 & 16.13 & $1,073-1,477$ & 405 & 134 & 15.75 \\
\hline $\mathrm{AC} 4$ & $2,251-2,427$ & 177 & 58 & 6.66 & $2,160-2,453$ & 294 & 97 & 11.09 \\
\hline NSP or BV1 & $312-1,244$ & 933 & 268 & 36.23 & $\ldots$ & $\ldots$ & $\ldots$ & $\ldots$ \\
\hline MP or BC1 & $1,301-2,146$ & 846 & 281 & 31.33 & $\ldots$ & $\ldots$ & $\ldots$ & $\ldots$ \\
\hline Unknown ORF & $\ldots$ & $\ldots$ & $\ldots$ & $\ldots$ & 291-1139 & 849 & 282 & 31.64 \\
\hline
\end{tabular}

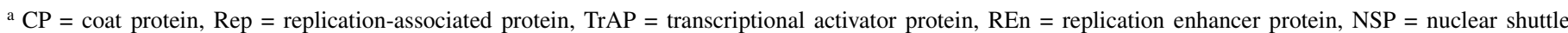
protein, and $\mathrm{MP}=$ movement protein.

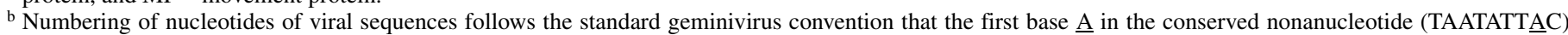
after the nick site in the origin of replication is designated nucleotide 1.

c Predicted molecular weight of the protein was calculated using the software program protein molecular weight.

A $\quad$ B
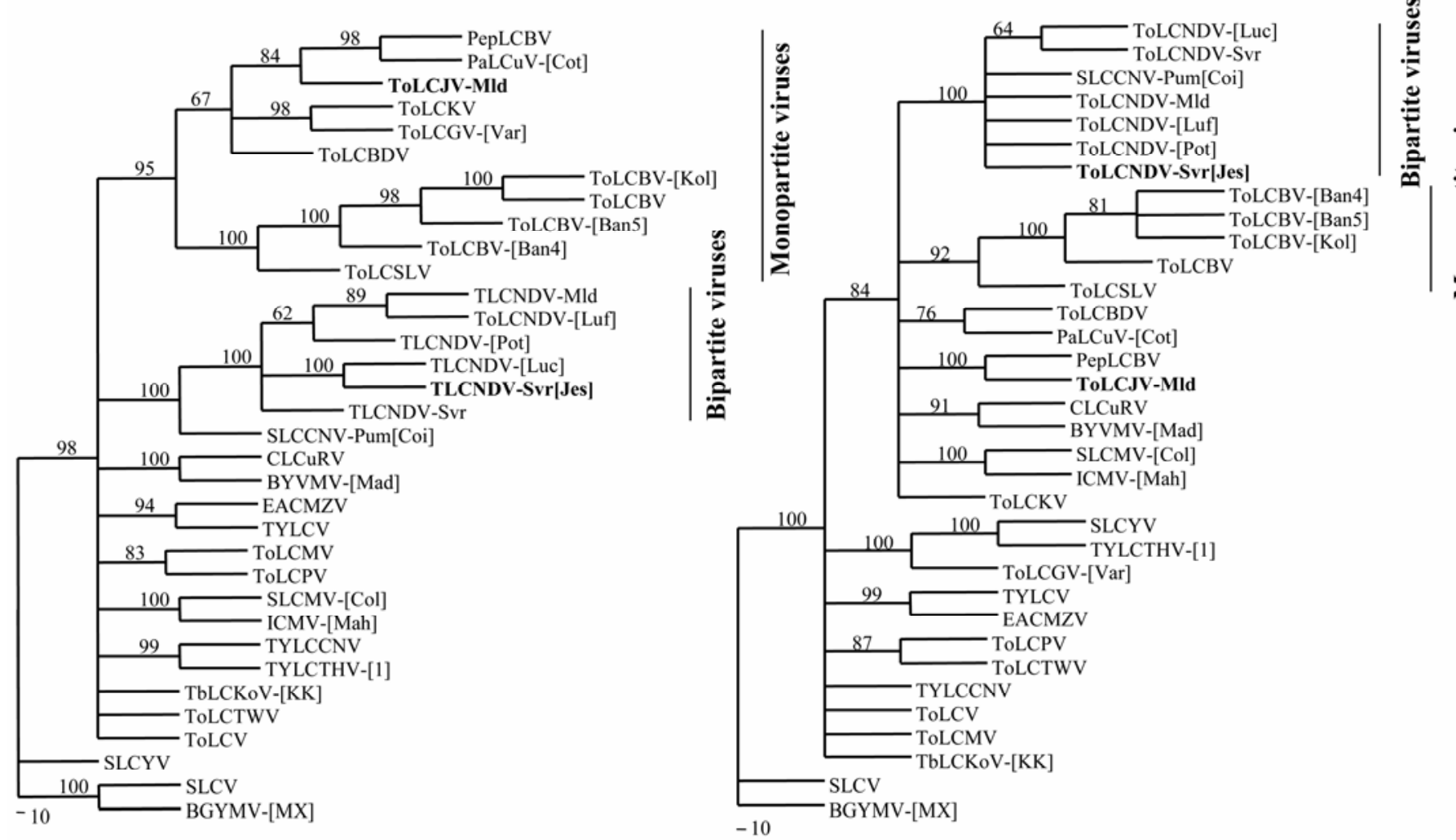

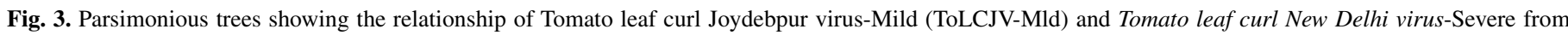

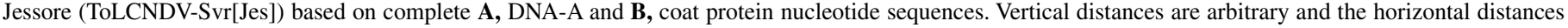

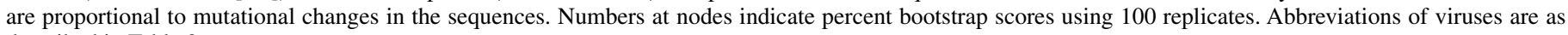
described in Table 2. 
ToLCVD incidence at Joydebpur was high (45\%) in TLB182 in the winter trial, but remained low on the three remaining resistant/tolerant cultivars (Table 6). Disease incidence reached $100 \%$ in cvs. BT1 and BT5 within 6 weeks after planting and disease spread was rapid in other local checks (Fig. 4B). ToLCVD pressure was very low at Jessore during the winter of 2003-04, where approximately $16 \%$ of plants of the susceptible checks became infected. The Jessore winter trial data, therefore, should be treated with caution.

Graft inoculation. The reaction of the three resistant/tolerant cultivars that were graft-inoculated with the mild ToLCJV-Mld and severe ToLCNDV-Svr[Jes] differed. Only 1 of 10 plants each of TLB111 and TLB130, and all of TLB182, showed mild symptoms 3 months after inoculation with ToLCJV-Mld. ToLCNDVSvr[Jes] infected all 10 TLB111 plants and produced mild symptoms, all 10 plants of TLB182 resulted in moderate symptoms, and all but one plant of TLB130 expressed moderate to severe symptoms.

The initial symptoms on the resistant/tolerant cultivars to the viruses varied. ToLCJV-Mld produced typical vein clearing symp- toms in the resistant/tolerant cultivars 2 weeks after grafting. In contrast, ToLCNDV-Svr[Jes] caused relatively mild symptoms after 3 weeks. Symptoms in the resistant/tolerant tomato cultivars appeared to subside (new growth was less affected) after 5 weeks and the plants continued to grow profusely compared with susceptible checks (Fig. 5). The mosaic-like symptoms developed by ToLCJV-Mld in cv. Moneymaker were not seen on the resistant/ tolerant cultivars.

\section{DISCUSSION}

At least three begomovirus species cause ToLCVD in Bangladesh. DNA-A nucleotide identities of the three viruses differed by 73.2 to $86.0 \%$, and their relative positions in phylogenetic trees suggest that they are distinct from each other and may have had different evolutionary pathways. Phylogenetic analyses of DNA-A and CP sequences clustered ToLCNDV-Svr[Jes] in a group comprising other strains of ToLCNDV reported from India (35). Based on A and B component sequences, ToLCNDV-Svr[Jes] was closest to ToLCNDV-[Luc] and ToLCGV-[Var] at 95.7 and $90.6 \%$

TABLE 5. Percent nucleotide identities for the complete genomes and genes of Bangladesh tomato leaf curl viruses (ToLCVs) with selected begomoviruses ${ }^{\text {a }}$

\begin{tabular}{|c|c|c|c|c|c|c|c|c|c|c|}
\hline Virus species & DNA-A & DNA-B & $\mathrm{CP}$ & AV2 & Rep & TrAP & REn & $\mathrm{AC} 4$ & NSP & MP \\
\hline \multicolumn{11}{|l|}{$\%$ Nucleotide identities of } \\
\hline \multicolumn{11}{|l|}{ ToLCNDV-Svr[Jes] with } \\
\hline ToLCJV-Mld & 74.4 & $\ldots$ & 80.9 & 79.6 & 75.3 & 69.8 & 73.3 & 80.2 & $\ldots$ & $\ldots$ \\
\hline ToLCBDV & 73.2 & $\ldots$ & 80.0 & 79.4 & 73.5 & 71.0 & 72.1 & 79.0 & $\ldots$ & $\ldots$ \\
\hline PepLCBV & 71.3 & $\ldots$ & 80.3 & 79.1 & 68.7 & 69.8 & 72.9 & 64.5 & $\ldots$ & $\ldots$ \\
\hline ToLCGV-[Var] & 72.2 & 90.6 & 73.9 & 78.2 & 75.1 & 70.8 & 70.9 & 80.7 & 91.5 & 93.2 \\
\hline CLCuRV & 72.1 & $\ldots$ & 77.9 & 73.2 & 73.6 & 72.9 & 72.1 & 81.6 & $\ldots$ & $\ldots$ \\
\hline ToLCTWV & 71.0 & $\ldots$ & 72.8 & 71.9 & 75.0 & 71.3 & $\ldots$ & 82.3 & $\ldots$ & $\ldots$ \\
\hline ICMV-[Mah] & 70.4 & 50.0 & 76.9 & 72.0 & 71.5 & 65.9 & 68.4 & 78.5 & 49.7 & 64.8 \\
\hline SLCCNV-Pum[Coi] & 87.3 & 66.2 & 94.0 & 96.8 & 84.7 & 84.5 & 84.9 & 89.8 & 70.8 & 79.4 \\
\hline ToLCBV group ${ }^{b}$ & $71.6-72.4$ & $\ldots$ & $75.4-76.9$ & $69.6-70.2$ & $73.8-74.7$ & $70.5-72.0$ & $71.9-72.1$ & $76.7-81.2$ & $\ldots$ & $\ldots$ \\
\hline ToLCNDV group $^{c}$ & $92.5-95.7$ & $85.0-88.6$ & $94.4-96.8$ & $95.3-97.6$ & $91.3-95.4$ & $94.8-98.3$ & 93.9-97.6 & $93.8-95.5$ & $87.4-89.4$ & $90.3-94.2$ \\
\hline \multicolumn{11}{|l|}{$\begin{array}{l}\% \text { Nucleotide identities of } \\
\text { ToLCJV-Mld with }\end{array}$} \\
\hline ToLCBDV & 86.0 & $\ldots$ & 91.3 & 91.9 & 88.3 & 86.2 & 82.7 & 90.8 & $\ldots$ & $\ldots$ \\
\hline PepLCBV & 87.1 & $\ldots$ & 97.5 & 96.1 & 79.2 & 97.3 & 98.0 & 64.9 & $\ldots$ & $\ldots$ \\
\hline ToLCGV-[Var] & 81.3 & $\ldots$ & 76.7 & 87.7 & 84.9 & 87.7 & 86.4 & 86.1 & $\ldots$ & $\ldots$ \\
\hline CLCuRV & 76.1 & $\ldots$ & 84.1 & 81.5 & 77.5 & 76.9 & 74.3 & 69.0 & $\ldots$ & $\ldots$ \\
\hline ToLCTWV & 77.6 & $\ldots$ & 78.0 & 77.8 & 83.4 & 73.1 & $\ldots$ & 88.1 & $\ldots$ & $\ldots$ \\
\hline ICMV-[Mah] & 75.9 & $\ldots$ & 84.3 & 80.4 & 74.2 & 77.5 & 75.3 & 74.2 & $\ldots$ & $\ldots$ \\
\hline SLCCNV-Pum[Coi] & 73.6 & $\ldots$ & 80.9 & 78.5 & 73.9 & 70.6 & 71.6 & 74.7 & $\ldots$ & $\ldots$ \\
\hline ToLCBV group $^{\mathrm{b}}$ & $79.5-81.1$ & $\ldots$ & $81.4-82.5$ & $77.6-78.2$ & $80.7-84.8$ & $86.7-88.9$ & $84.0-85.9$ & $84.7-92.5$ & $\ldots$ & $\ldots$ \\
\hline ToLCNDV group $^{c}$ & $73.9-74.2$ & $\ldots$ & $80.1-81.5$ & $77.3-79.4$ & $74.7-75.2$ & $68.8-69.8$ & $73.1-72.4$ & $77.5-80.3$ & $\ldots$ & $\ldots$ \\
\hline
\end{tabular}

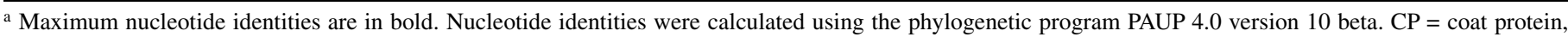
Rep $=$ replication-associated protein, TrAP $=$ transcriptional activator protein, $\mathrm{REn}=$ replication enhancer protein, NSP $=$ nuclear shuttle protein, and MP $=$ movement protein.

b Comparisons were made for strains of ToLCBV, ToLCBV-[Kol], ToLCBV-[Ban5], and ToLCBV-[Ban4].

c Comparisons were made for strains of ToLCNDV-[Luc], ToLCNDV-[Luf], ToLCNDV-Mld, ToLCNDV-[Pot], and ToLCNDV-Svr.

TABLE 6. Performance of resistant/tolerant tomato cultivars to tomato leaf curl virus (ToLCV) of Bangladesh during the summer and winter seasons of $2003-04$

\begin{tabular}{|c|c|c|c|c|c|c|c|c|c|c|}
\hline \multirow[b]{3}{*}{$\begin{array}{l}\text { Tomato } \\
\text { cultivar }\end{array}$} & \multicolumn{4}{|c|}{ Summer season screening trial (Jun. - Sept. 2003) } & \multicolumn{6}{|c|}{ Winter season screening trial (Nov. 2003 - Feb. 2004) } \\
\hline & \multicolumn{2}{|c|}{ Jessore } & \multicolumn{2}{|c|}{ Joydebpur } & \multicolumn{2}{|c|}{ Jessore } & \multicolumn{4}{|c|}{ Joydebpur } \\
\hline & $\begin{array}{c}\text { No. of } \\
\text { plants infected/ } \\
\text { planted }(\%)\end{array}$ & $\begin{array}{l}\text { Mean } \\
\text { severity } \\
\text { index }^{\mathrm{a}}\end{array}$ & $\begin{array}{c}\text { No. of } \\
\text { plants infected/ } \\
\text { planted }(\%)\end{array}$ & $\begin{array}{c}\text { Mean } \\
\text { severity } \\
\text { index }^{\mathrm{a}}\end{array}$ & $\begin{array}{c}\text { No. of } \\
\text { plants infected/ } \\
\text { planted }(\%)\end{array}$ & $\begin{array}{l}\text { Mean } \\
\text { severity } \\
\text { index }^{\mathrm{a}}\end{array}$ & $\begin{array}{c}\text { No. of } \\
\text { plants infected/ } \\
\text { planted }(\%)\end{array}$ & $\begin{array}{c}\text { Mean } \\
\text { severity } \\
\text { index }^{\mathrm{a}}\end{array}$ & $\begin{array}{c}\text { No. of } \\
\text { fruits/ } \\
10 \text { plants }^{\mathrm{b}}\end{array}$ & $\begin{array}{c}\text { Fruit } \\
\text { yield/ha } \\
(\mathrm{kg})\end{array}$ \\
\hline TLB111 & $9 / 60(15)$ & 1.5 & $4 / 64(6)$ & 1.5 & $2 / 87(2)$ & 1.0 & $19 / 79(24)$ & 1.7 & 181 & 20,416 \\
\hline TLB 130 & $16 / 60(27)$ & 1.7 & $10 / 65(15)$ & 1.8 & $5 / 88(6)$ & 2.0 & $9 / 79(11)$ & 2.2 & 258 & 33,243 \\
\hline TLB133 & $18 / 58(31)$ & 1.8 & $6 / 67(9)$ & 1.1 & $6 / 78(8)$ & 2.6 & $12 / 84(14)$ & 1.9 & 272 & 28,575 \\
\hline TLB182 & $16 / 57(28)$ & 2.0 & $6 / 64(9)$ & 2.5 & $8 / 89$ (10) & 1.9 & $38 / 84(45)$ & 2.3 & 187 & 26,317 \\
\hline $\mathrm{BT} 1^{\mathrm{c}}$ & $\ldots$ & $\ldots$ & $\ldots$ & $\ldots$ & $8 / 90(9)$ & 2.8 & $82 / 82(100)$ & 2.1 & 56 & 15,272 \\
\hline $\mathrm{BT} 2^{\mathrm{c}}$ & $\ldots$ & $\ldots$ & $\ldots$ & $\ldots$ & $8 / 88(8)$ & 3.0 & $55 / 74(74)$ & 2.0 & 77 & 18,729 \\
\hline BT5 & $41 / 60(68)$ & 2.0 & $49 / 70(70)$ & 2.0 & $14 / 85$ (16) & 2.3 & $81 / 81(100)$ & 2.3 & 164 & 19,517 \\
\hline BT10 & $43 / 57(75)$ & 2.4 & $54 / 68$ (79) & 2.9 & $7 / 89(8)$ & 1.8 & $63 / 83(76)$ & 2.1 & 230 & 21,230 \\
\hline
\end{tabular}

${ }^{a}$ Mean severity index was calculated by dividing the total severity score by the number of diseased plants.

${ }^{\mathrm{b}}$ Fruit yield data were recorded in the winter season trial of 2003-04 at Joydebpur only.

c Not included in summer season trial because BT1 and BT2 are exclusively winter cultivars. 


\section{A Summer trial 2003}

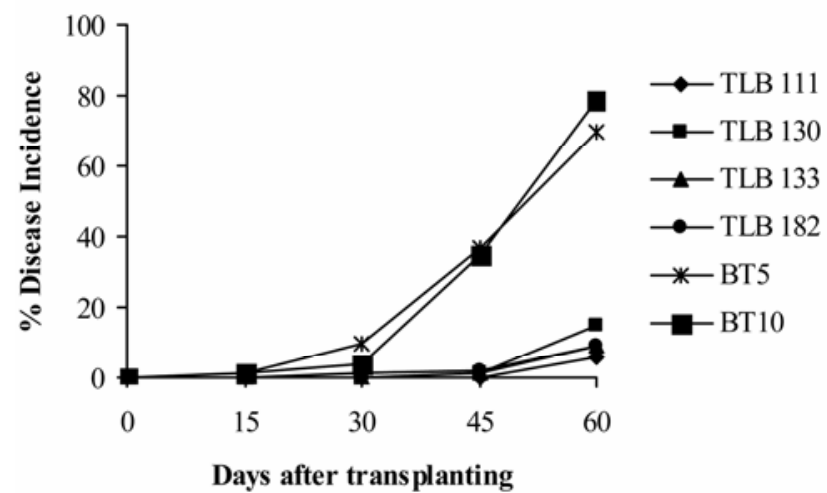

B Winter trial 2003-04

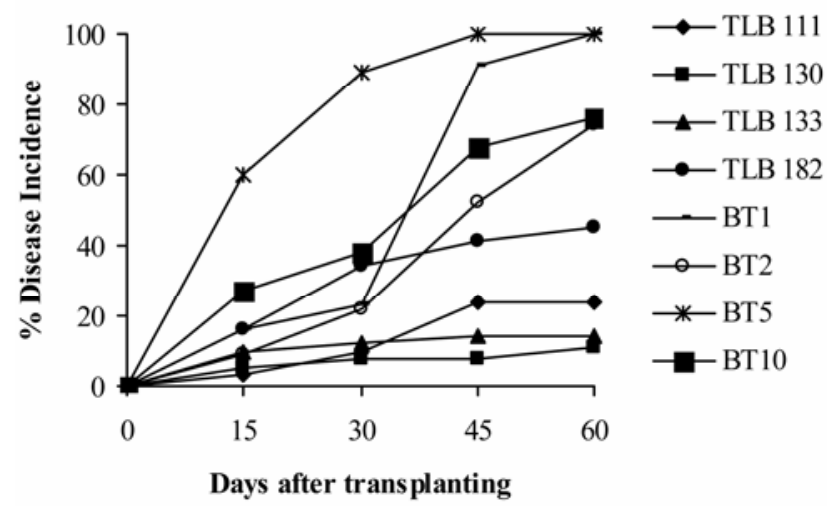

Fig. 4. Spread of Tomato leaf curl virus (ToLCV) disease in Bangladesh. Resistant/tolerant tomato cultivars were compared against the local susceptible cultivars during the summer and winter seasons of 2003-04 nt identities, respectively. High similarities based on full-length genome components and genes indicated that ToLCNDV-Svr[Jes] was an isolate of bipartite ToLCNDV.

Phylogenetic analyses of DNA-A and CP sequences clustered ToLCJV-Mld into a group with the monopartite PepLCBV and shared highest identity of $87.1 \%$ with it. The phylogenetic grouping, failure to amplify the DNA-B component by PCR tests, and the successful detection of a satellite DNA- $\beta$ collectively indicated that ToLCJV-Mld is a monopartite virus. ToLCJV-Mld can be classified as a novel begomovirus species $(9,10)$ because of the $<89 \%$ DNA-A sequence identities to other begomoviruses. All the genes of ToLCJV-Mld were conserved with nucleotide identities $\geq 92 \%$ to PepLCBV, except Rep, which shared the maximum $88.3 \%$ nt identity with ToLCBDV. This may indicate the occurrence of a recombination event in the Rep region of ToLCJV-Mld, and this region is regarded as a "recombination hotspot" in monopartite begomoviruses (19). The nucleotide identities and arrangement of the genes, however, indicated that both the viruses are from the Old World and belong to the genus Begomovirus of the family Geminiviridae.

The high genetic diversity of tomato-infecting begomoviruses in Bangladesh was expected, because such variability has been documented in the neighboring country of India, based on epitope profiles of viruses (32) and, to date, at least four ToLCV species with several strains have been identified $(6,9)$. Work on the geographical distribution of ToLCVs within India suggested that bipartite viruses occur in the north while the monopartite viruses are restricted to the south $(6,16,19,33)$. More recently, however, a monopartite ToLCBV has been found infecting cotton in north India (20). Results of this study provide evidence that both monoand bipartite viruses are likely to occur in the north of India because both types of virus were detected in neighboring Bangladesh.

There are no previous reports of vector transmission of ToLCVs from Bangladesh. In this study, ToLCNDV-Svr[Jes], ToLCJVMld, and an uncharacterized field isolate from Joydebpur were transmitted by B. tabaci. Evidence of the rate of vector transmission was provided in the form of disease spread in field trials. B. tabaci required short AAP (30 min) and IAP (15 min), with the maximum transmission occurring after 24-h AAP and IAP. These

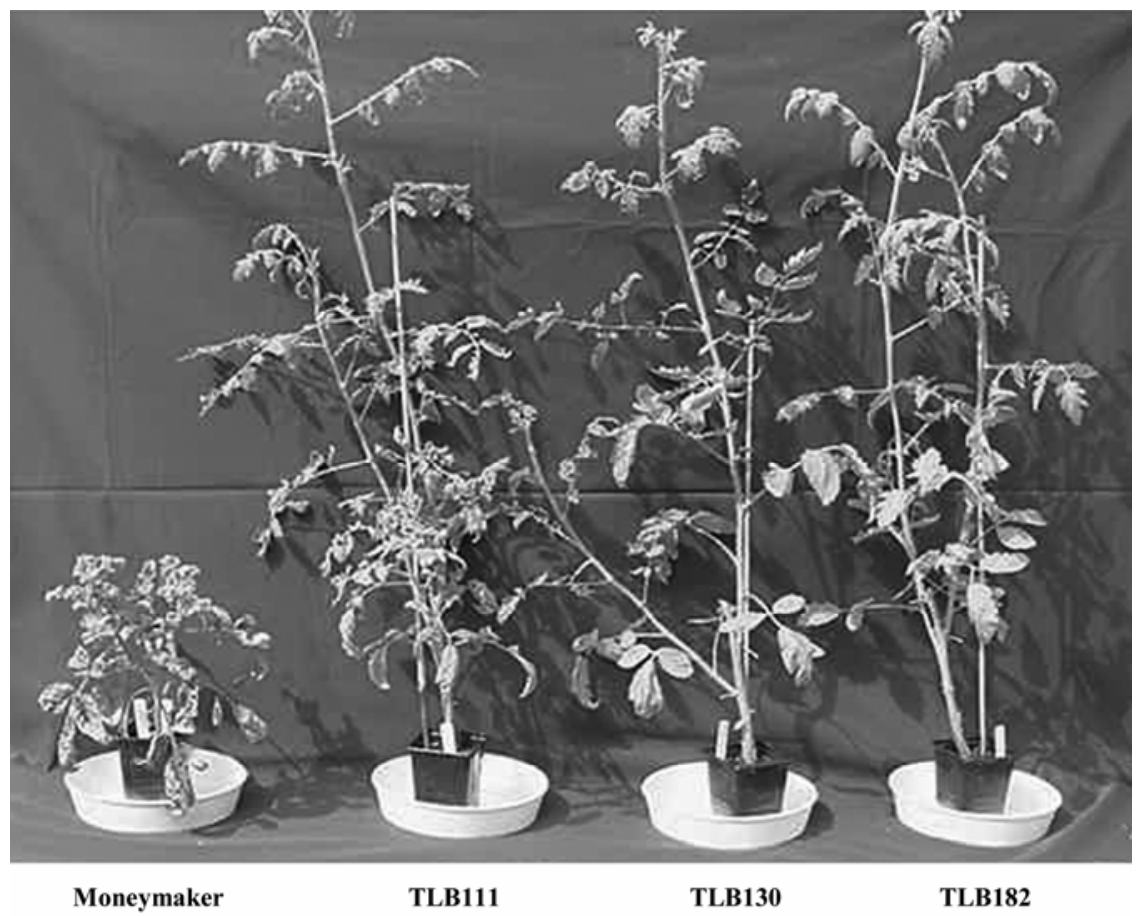

Fig. 5. Symptoms produced in resistant/tolerant and susceptible tomato cultivars at the Natural Resources Institute (UK) after graft inoculation of Tomato leaf curl New Delhi virus-Severe from Jessore (ToLCNDV-Svr[Jes]). 
data are consistent with the transmission pattern recorded for begomoviruses in India (30,33).

Considerable efforts to develop resistant tomato cultivars during the last 2 decades in India $(1,17,25,26,29)$ have resulted in the development of tomato cultivars that are resistant/tolerant to ToLCVD, and which also have acceptable horticultural properties (31). The low economic damage caused by ToLCVD previously in Bangladesh may be a reason for the lack of such attempts in this region to develop ToLCVD-resistant tomato cultivars. However, the results of field trials demonstrate that the incidence of ToLCVD can reach damaging levels in popularly grown cultivars such as the BT series released for cultivation by BARI.

Conventional breeding for ToLCVD resistance is a slow and difficult process $(1,14,37)$, and so the south Indian resistant/ tolerant tomato cultivars already available were screened against the Bangladesh ToLCVs to assess their potential for use in this new region. The results obtained in two consecutive seasons of 2003-04 at both Joydebpur and Jessore were concordant and indicated that the south Indian tomato cultivars also were tolerant to ToLCVs from Bangladesh. Disease incidence in tomato cultivars differed slightly between seasons and locations and this may have been due to several factors including differences in whitefly numbers, largely influenced by rainfall, but mostly by the occurrence of different virus types (both mono- and bipartite) and potential mixed infections, although none were found in this study. These sources of variability were removed by inoculating each virus separately by grafting under controlled conditions. Results indicated that TLB182 was the most susceptible, with symptoms expressed soon after inoculation by each virus. TLB111 was least susceptible, as only one plant expressed mild symptoms upon inoculation with the mild ToLCJV-Mld. Moreover, only mild symptoms were caused by the severe ToLCNDV-Svr[Jes]. The ability of these cultivars to grow profusely and produce high yields (Table 6) both in the winter and summer seasons and their tolerance when challenged by diverse groups of viruses in the glasshouse and almost certainly by the mixture of viruses in the field may provide an effective means of managing ToLCVD in Bangladesh with reduced insecticide use.

\section{ACKNOWLEDGMENTS}

We thank M. Thresh for critical reviews of early drafts of the manuscript and C. Black and N. Morley for maintaining the virus cultures and whitefly colonies. This publication is an output of a project (contract no. ICA4-CT-2002-10018) funded by the European Union. The begomoviruses and whiteflies were held under the DEFRA licenses PHL 176A/4735 and PHL 176/4251.

\section{LITERATURE CITED}

1. Banerjee, M. K., and Kalloo. 1987. Sources and inheritance of resistance to leaf curl virus in Lycopersicon. Theor. Appl. Genet. 73:707-710.

2. Briddon, R. W., Bull, S. E., Amin, I., Idris, A. M., Mansoor, S., Bedford, I. D., Dhawan, P., Rishi, N., Siwatch, S. S., Abdel-Salam, A. M., Brown, J. K., Zafar, Y., and Markham, P. G. 2003. Diversity of DNA- $\beta$, a satellite molecule associated with some monopartite begomoviruses. Virology 312:106-121.

3. Briddon, R. W., Bull, S. E., Amin, I., Mansoor, S., Bedford, I. D., Rishi, N., Siwatch, S. S., Zafar, Y., Abdel-Salam, A. M., and Markham, P. G. 2004. Diversity of DNA 1: A satellite-like molecule associated with monopartite-DNA- $\beta$ complexes. Virology 324:462-474.

4. Briddon, R. W., Bull, S. E., Mansoor, S., Amin, I., and Markham, P. G. 2002. Universal primers for the PCR-mediated amplification of DNA- $\beta$ : A molecule associated with monopartite begomoviruses. Mol. Biotechnol. 20:315-318.

5. Briddon, R. W., Mansoor, S., Bedford, I. D., Pinner, M. S., Saunders, K., Stanley, J., Zafar, Y., Malik, K., and Markham, P. G. 2001. Identification of DNA components required for induction of cotton leaf curl disease. Virology 285:234-243.

6. Chowda Reddy, R. V., Colvin, J., Muniyappa, V., and Seal, S. 2005. Diversity and distribution of begomoviruses infecting tomato in India. Arch. Virol. 150:845-867.
7. Deng, D., McGrath, P. F., Robinson, D. J., and Harrison, B. D. 1994. Detection and differentiation of whitefly-transmitted geminiviruses in plants and vector insects by the polymerase reaction with degenerate primers. Ann. Appl. Biol. 125:327-336.

8. Dry, I. B., Rigden, J. E., Krake, L. R., Mullineaux, P. M., and Rezaian, A. 1993. Nucleotide sequence and genome organization of tomato leaf curl geminivirus. J. Gen. Virol. 74:147-151.

9. Fauquet, C. M., Bisaro, D. M., Briddon, R. W., Brown, J. K., Harrison, B. D., Rybicki, E. P., Stenger, D. C., and Stanley, J. 2003. Revision of taxonomic criteria for species demarcation in the family Geminiviridae, and an updated list of begomovirus species. Arch. Virol. 148:405-421.

10. Fauquet, C. M., and Stanley, J. 2003. Geminivirus classification and nomenclature; Progress and problems. Ann. Appl. Biol. 142:165-189.

11. Green, S. K., Tsai, W. S., Shih, S. L., Black, L. L., Rezajan, A., Rashid, M. H., Roff, M. M. N., Myint, Y. Y., and Hong, L. T. A. 2001. Molecular characterization of begomoviruses associated with leaf curl diseases of tomato in Bangladesh, Laos, Malaysia, Myanmar, and Vietnam. Plant Dis. $85: 1286$.

12. Gutierrez, C. 2002. Strategies for geminivirus DNA replication and cell cycle interference. Physiol. Mol. Plant Pathol. 60:219-230.

13. Hanley-Bowdoin, L., Settlage, S. B., Orozco, B. M., Nagar, S., and Robertson, D. 1999. Geminiviruses: Models for plant DNA replication, transcription, and cell cycle regulation. Crit. Rev. Plant Sci. 18:71-106.

14. Hanson, P. M., Bemacchi, D., Green, S. K., Tanksley, S. D., Muniyappa, V., Padmaja, A. S., Chen, H. M., Kuo, G., Fang, D., and Chen, J. T. 2000. Mapping a wild tomato introgression associated with tomato yellow leaf curl virus resistance in a cultivated tomato line. J. Am. Soc. Hortic. Sci. 125:15-20.

15. Harrison, B. D., Swanson, M. M., and Fargette, D. 2002. Begomovirus coat protein: Serology, variation and functions. Physiol. Mol. Plant Pathol. 60:257-271.

16. Hong, Y. G., and Harrison, B. D. 1995. Nucleotide sequences from tomato leaf curl viruses from different countries: Evidence for three geographically separate branches in evolution of the coat protein of whiteflytransmitted geminiviruses. J. Gen. Virol. 76:2043-2049.

17. Joshi, G. C., and Choudhury, B. 1981. Screening Lycopersicon and Solanum species for resistance to leaf curl virus. Veg. Sci. 8:45-50.

18. Kheyr-Pour, A., Bendahmane, M., Matzeit, V., Accotto, G. P. M., Crespi, S., and Gronenborn, B. 1991. Tomato yellow leaf curl virus from Sardinia is a whitefly-transmitted monopartite geminivirus. Nucleic Acid Res. 19:6763-6769.

19. Kirthi, N., Maiya, S. P., Murthy, M. R. N., and Savithri, H. S. 2002. Evidence of recombination among the tomato leaf curl virus strains/ species from Bangalore, India. Arch. Virol. 147:255-272.

20. Kirthi, N., Priyadarshini, C. G. P., Sharma, P., Maiya, S. P., Hemalatha, V., Sivaraman, P., Dhawan, P., Rishi, N., and Savitri, H. S. 2004. Genetic variability of begomoviruses associated with cotton leaf curl disease originating from India. Arch. Virol. 149:2047-2057.

21. Maleque, M. A., Kabir, K. H., Khanam, N. N., Alam, S. N., and Islam, N. 2002. Combined effect of planting date and variety of tomato on the incidence of whitefly, Bemisia tabaci (Gennadius) and virus diseases. Bangladesh J. Zool. 30:159-165.

22. Maruthi, M. N., Colvin, J., Gibson, G., Thwaites, R. M., Banks, G. K., and Seal, S. E. 2004. Reproductive incompatibility and cytochrome oxidase I gene sequence variability amongst host-adapted and geographically separate Bemisia tabaci populations. Syst. Entomol. 29:560-568.

23. Maruthi, M. N., Colvin, J., and Seal, S. 2001. Mating compatibility, lifehistory traits and RAPD-PCR variation in Bemisia tabaci associated with the cassava mosaic disease pandemic in East Africa. Entomol. Exp. Appl. 99:13-23.

24. Maruthi, M. N., Colvin, J., Seal, S., Gibson, G., and Cooper, J. 2002. Coadaptation between cassava mosaic geminiviruses and their local vector populations. Virus Res. 86:71-85.

25. Maruthi, M. N., Czosnek, H., Vidavski, F., Tarba, S.-Y., Milo, J., Leviatov, S., Venkatesh, H. M., Padmaja, A. S., Kulkarni, R. S., and Muniyappa, V. 2003. Comparison of resistance to Tomato leaf curl virus (India) and Tomato yellow leaf curl virus (Israel) among Lycopersicon wild species, breeding lines and hybrids. Eur. J. Plant Pathol. 109:1-11.

26. Maruthi, M. N., Muniyappa, V., Green, S. K., Colvin, J., and Hanson, P. 2003. Screening tomato and sweet-pepper genotypes resistance to Tomato leaf curl Bangalore virus and its vector Bemisia tabaci. Int. J. Pest Manag. 49:297-303.

27. Maruthi, M. N., Rekha, A. R., Cork, A., Colvin, J., Alam, S. N., and Kader, K. A. 2005. A novel begomovirus with distinct genomic and phenotypic features infects tomato in Bangladesh. New Disease Reports, Vol. 11. Published online by The British Society for Plant Pathology (http://www.bspp.org.uk/ndr/).

28. Maruthi, M. N., Rekha, A. R., Cork, A., Colvin, J., Alam, S. N., and Kader, K. A. 2005. First report of Tomato leaf curl New Delhi virus infecting tomato in Bangladesh. Plant Dis. 89:1011. 
29. Muniyappa, V., Jalikop, S. H., Saikia, A. K., Chennarayappa, Shivashankar, G., Ishwarabhat, A., and Ramappa, H. K. 1991. Reaction of Lycopersicon cultivars and wild accessions to tomato leaf curl virus. Euphytica 56:37-41.

30. Muniyappa, V., Maruthi, M. N., Babitha, C. R., Colvin, J., Briddon, R. W., and Rangaswamy, K. T. 2003. Characterization of pumpkin yellow vein mosaic virus from India. Ann. Appl. Biol. 142:323-331.

31. Muniyappa, V., Padmaja, A. S., Venkatesh, H. M., Sharma, A., Chandrashekar, S., Kulkarni, R. S., Hanson, P. M., Chen, J. T., Green, S. K., and Colvin, J. 2002. Tomato leaf curl virus resistant tomato lines TLB111, TLB130, and TLB182. HortScience 37:603-606.

32. Muniyappa, V., Swanson, M. M., Duncan, G. H., and Harrison, B. D. 1991. Particle purification, properties and epitope variability of Indian tomato leaf curl geminivirus. Ann. Appl. Biol. 118:595-604.

33. Muniyappa, V., Venkatesh, H. M., Ramappa, H. K., Kulkarni, R. S., Zeidan, M., Tarba, C.-Y., Ghanim, M., and Czosnek, H. 2000. Tomato leaf curl virus from Bangalore (ToLCV-Ban4): Sequence comparison with Indian ToLCV isolates, detection in plants and insects, and vector relationships. Arch. Virol. 145:1583-1598.

34. Navot, N., Pichersky, E., Zeidan, M., Zamir, D., and Czosnek, H. 1991. Tomato yellow leaf curl virus: A whitefly transmitted geminivirus with a single genomic molecule. Virology 183:151-161.

35. Padidam, M., Beachy, R. N., and Fauquet, C. M. 1995. Tomato leaf curl geminivirus from India has a bipartite genome and coat protein is not essential for infectivity. J. Gen. Virol. 76:25-35.
36. Pico, B., Diez, M. J., and Nuez, F. 1998. Evaluation of whitefly-mediated inoculation techniques to screen Lycopersicon esculentum and wild relatives for resistance to tomato yellow leaf curl virus. Euphytica 101:259-271.

37. Pilowsky, M., and Cohen, S. 1990. Tolerance to tomato yellow leaf curl virus derived from Lycopersicon peruvianum. Plant Dis. 74:248-250.

38. Saikia, A. K., and Muniyappa, V. 1989. Epidemiology and control of tomato leaf curl virus in Southern India. Trop. Agric. (Trinidad) 66:350-354.

39. Saunders, K., Bedford, I. D., Briddon, R. W., Markham, P. G., Wong, S. M., and Stanley, J. 2000. A unique virus complex causes Ageratum yellow vein disease. Proc. Natl. Acad. Sci. USA 97:6890-6895.

40. Saunders, K., Norman, A., Gucciardo, S., and Stanley, J. 2004. The DNA$\beta$ satellite component associated with ageratum yellow vein disease encodes an essential pathogenicity protein ( $\beta C 1)$. Virology 324:37-47.

41. Stanley, J. 2004. Subviral DNAs associated with geminivirus disease complexes. Vet. Microbiol. 98:121-129.

42. Swofford, D. L. 2002. PAUP*: Phylogenetic Analysis Using Parsimony (and other Methods) version 4.0. Sinauer Associates, Sunderland, MA

43. Varma, J. P. 1959. Tomato leaf curl. Pages 182-200 in: Proc. ICAR Seminar on Disease of Horticulture Plants, Simla, India.

44. Vasudeva, R. S., and Samraj, J. 1948. A leaf curl disease of tomato. Phytopathology 38:364-369.

45. Zhou, X., Xie, Y., Tao, X., Zhang, Z., Li, Z., and Fauquet, C. M. 2003. Characterization of DNA- $\beta$ associated with begomovirus in China and evidence for co-evolution with their cognate viral DNA-A. J. Gen. Virol. 84:237-247. 